\title{
Sexual Orientation and Gender Identity Discrimination Claims Under the Fair Housing Act After Bostock v. Clayton County
}

\author{
Rigel C. Oliveri*
}

INTRODUCTION

On June 15, 2020, the Supreme Court handed down a landmark decision in Bostock v. Clayton County, Georgia, ${ }^{1}$ ruling by a vote of 6-3 that Title VII of the Civil Rights Act of $1964^{2}$ protects gay, lesbian, and transgender employees from discrimination. The majority held that the statute's prohibition against discrimination in employment "because of . . . sex" necessarily applies to discrimination based on sexual orientation and transgender identity. ${ }^{3}$

This decision will undoubtedly have ramifications reaching beyond the employment context because many other federal statutes contain language similar to that in Title VII. In particular, the federal Fair Housing Act (FHA), ${ }^{4}$ which has identical language prohibiting discrimination in housing "because of . . sex," 5 should also now be interpreted to prohibit discrimination based on sexual orientation and gender identity. This is an obvious next step given the similar language, structure, and purpose of both statutes, and the courts' long-standing tendency to use Title VII cases to guide their interpretation of the FHA. This would also be a welcome development for housing equity, considering the significant discrimination that gay, lesbian, and transgender individuals experience in housing and the dearth of legal protections in place for them.

It may be tempting for advocates to simply point to the textual similarity between the statutes and declare the matter resolved. We should go further, however, because it is important to understand how the

\footnotetext{
* Isabelle Wade and Paul C. Lyda Professor of Law, University of Missouri. B.A. University of Virginia, J.D. Stanford Law School. The author was formerly a Trial Attorney for the United States Department of Justice, Civil Rights Division, in the Housing \& Civil Enforcement Section. The author thanks Paul Litton for feedback on early drafts of this piece.

1. 140 S. Ct. 1731 (2020).

2. 42 U.S.C. $\S \S 2000 \mathrm{e}-2000 \mathrm{e}-17$.

3. Bostock, 140 S. Ct. at 1754.

4. 42 U.S.C. $\S \S 3601-3631$.

5. Id. at $\S 3604(\mathrm{a})$.
} 
reasoning behind Title VII cases applies to the FHA. It is not always true that Title VII analysis developed in the workplace context can translate seamlessly to the housing context, even when the statutory language is similar or identical. In this case, however, the Title VII analysis applies equally well, if not better, in the FHA context.

There is one area that presents a potential hurdle: the problem of mixed motives. Whether discrimination is "based on sex" is ultimately a causation argument. The court must determine what role the characteristic of "sex" played in the defendant's decision to discriminate against an LGBTQ individual. Defendants in discrimination cases often offer a nonprohibited reason for their actions. Where there are two or more possible motivations behind a discriminatory act (one permissible and one prohibited), the court is confronted with a mixed motives scenario. The Supreme Court, interpreting the phrase "because of sex," set forth a manner for plaintiffs to proceed under such circumstances in Title VII cases. Congress then amended Title VII to explicitly allow plaintiffs to proceed under a mixed motives theory, though it altered the Supreme Court's framework. The Supreme Court has never addressed the issue of mixed motives under the FHA, nor has the statute been amended as Title VII was. If Bostock's reasoning relies on the mixed motives theory, it might not be so easy to apply its conclusions to the FHA.

Fortunately, for fair housing advocates, this is not the case. Although much of the Bostock opinion examines the causal role that sex plays in sexual orientation and gender identity discrimination, ${ }^{6}$ it ultimately determines that the issue does not create a mixed motives question. Bostock does not hold that defendants who discriminate against LGBTQ individuals are motivated by both discrimination based on sex and discrimination based on another, permissible characteristic. Rather, Bostock holds that sex discrimination is inextricably linked to discrimination based on sexual orientation and gender identity. ${ }^{7}$ Thus, the mixed motive issue never arises, and the differences between the two statutes on this point are irrelevant.

Part I of this Article outlines the significant level of discrimination against LGBTQ individuals in the housing market. The FHA does not specify that sexual orientation and gender identity are protected characteristics, and there is an insufficient patchwork of state statutory and administrative protections. This is similar to the employment context, where Congress's failure to include explicit protections for LGTBQ individuals in Title VII left the heavy-lifting to the courts, which gradually

6. Bostock, 140 S. Ct. at $1739-43$.

7. Id. at $1746-47$. 
developed doctrines to read such protections back into the statute.

Part II reviews the courts' evolving treatment of sexual orientation and gender identity under Title VII and the smaller number of cases following the same pattern in the FHA. In particular, those courts which upheld plaintiffs' claims relied on three types of arguments: (1) the argument that LGBTQ individuals defy sex-role stereotypes, and that sex-role stereotyping constitutes discrimination "based on sex," (2) a textual "comparative argument," which looks in many ways like a causation analysis, and (3) a related associational argument. This Part concludes with a discussion of the Supreme Court's opinion in Bostock, which relied heavily on the comparative argument.

Part III analyzes how courts use Title VII precedent for guidance in fair housing cases. It argues that the propriety of this practice will depend on whether there are any relevant differences between the employment and housing contexts. In this case, there are no significant contextual differences, and thus Bostock's interpretation of "because of sex" should apply equally to sexual orientation and gender identity discrimination claims brought under the FHA. Indeed, as with Title VII, there is strong precedent in favor of broadly interpreting the FHA to cover claims and plaintiffs that Congress may not have originally intended to cover.

Part IV examines the possible mixed motives issue. It discusses the potential for the "because of sex" causation argument to implicate mixed motives. It also examines the potential for the differences between the two statutes to complicate attempts to apply Bostock to the FHA. This is not a problem, however, because Bostock's reasoning does not in fact implicate mixed motives at all. Thus, there is no reason not to apply Bostock's holding to the FHA.

\section{SEXUAL ORIENTATION AND TRANSGENDER IDENTITY DISCRIMINATION IN HOUSING}

\section{A. Housing Discrimination Against LGBTQ Individuals}

Housing discrimination is a problem for gay and transgender individuals. Survey studies indicate that a sizable percentage (73\%) of gay and transgender individuals fear such discrimination, ${ }^{8}$ and that whether a state has legal protections against such discrimination is a significant factor for many when determining where to live. ${ }^{9}$ In a 2001 survey by the

8. 2015 LGBT Home Buyer and Seller Survey, NAT'L ASS'N OF GAY \& LESBIAN REAL EST. PROS. 3, 17 (2015), https://naglrep.com/wp-content/uploads/2017/06/naglrep-lgbt-survey-2015.pdf [https://perma.cc/7EJN-73PX].

9. Id. at 3,13 . 
Kaiser Family Foundation, 34\% of gay and lesbian respondents reported that they or someone they knew had experienced discrimination when seeking to rent or buy a house. ${ }^{10}$

Research studies, including matched pair testing, also indicate discrimination against LGBTQ individuals, although the extent of the discrimination they measure varies based on the form of the test performed. A 2013 study that relied on email contacts found that samesex couples were significantly less likely to receive responses to email inquiries than heterosexual couples. ${ }^{11}$ Studies that relied on telephone or in-person testing report higher rates of discrimination, even in states with legal prohibitions against such behavior. For example, testing conducted by four fair housing centers in Michigan found that $27 \%$ of the tests showed a disparity in treatment based on sexual orientation, including differences in rental rates, level of encouragement, and application fees, all favoring the heterosexual test teams. ${ }^{12}$ The researchers also observed "behavior bordering on sexual harassment directed toward testers posing as same-sex couples." 13

In 2017, the Urban Institute conducted a multi-state, in-person testing project, the most significant such project to date. ${ }^{14}$ The researchers found that gay men posing as housing-seekers were told about fewer units and quoted higher rental fees than straight testers. ${ }^{15}$ Transgender testers were less likely to be told about available units, or were told about fewer units,

10. Inside-OUT: A Report on the Experiences of Lesbians, Gays and Bisexuals in America and the Public's Views on Issues and Policies Related to Sexual Orientation, KAISER FAM. FOUND. Chart 4 (Nov. 2001), https://www.kff.org/wp-conte nt/uploads/2013/01/new-surveys-on-experiences-of-lesbians-gays-and-bisexuals-and-the-public-sviews-related-to-sexual-orientation-chart-pack.pdf [https://perma.cc/EA7C-PTQG]. Interestingly, in the same survey, $74 \%$ of the general public surveyed expressed support for "[1]aws to protect gays and lesbians from prejudice and discrimination in housing." Id. at Chart 17.

11. Samantha Friedman, Angela Reynolds, Susan Scovill, Florence R. Brassier, Ron Campbell \& McKenzie Ballou, An Estimate of Housing Discrimination Against Same-Sex Couples, U.S. DeP'T Hous. \& UrB. Dev. iv (2013), https://www.huduser.gov/portal/publications/fairhsg/discrim_samesex.html [https://perma.cc/QP64 $-6 \mathrm{SJL}]$.

12. Sexual Orientation and Housing Discrimination in Michigan: A Report of Michigan's Fair Housing Centers, FAIR HOUS. CTR. OF S.E. MICH. 9 (2007), https://www.fhcmichigan.org/ images/Arcus_web1.pdf [https://perma.cc/USX3-P23J].

13. Id.

14. Diane K. Levy, Doug Wissoker, Claudia L. Aranda, Brent Howell, Rob Pitingolo, Sarale Sewell \& Rob Santos, A Paired-Testing Pilot Study of Housing Discrimination Against Same-Sex Couples and Transgender Individuals, URB. INST. viii (2017), https://www.urban.org/research/publication/paired-testing-pilotstudy-housing-discrimination-against-same-sex-couples-and-transgenderindividuals/view/full_report [https://perma.cc/3KXL-P7VJ].

15. Id. at xiii. 
than cisgender testers. ${ }^{16}$ Another nationwide study noted an intersectional effect: while all same-sex couples were told about fewer units than heterosexual couples, black same-sex couples were treated even worse than white same-sex couples. ${ }^{17}$

The problem is particularly acute for older LGBTQ individuals seeking to live in facilities for senior living. Self-reports of discrimination against this group are high - in one survey of older LGBTQ individuals, $13 \%$ of respondents reported that they had been discriminated against based on their sexual orientation and $25 \%$ of transgender older adults reported being discriminated against based on their gender identity. ${ }^{18}$ The actual numbers may be even higher, as victims of housing discrimination are often not aware that they have been discriminated against. In 2014, a national investigation found that $48 \%$ of older LGBTQ people inquiring about housing in a senior living facility experienced "adverse differential treatment" and profound discrimination, including being given less information about available units, being charged higher fees, and being outright denied housing. ${ }^{19}$

\section{B. Lack of Legal Protections}

LGBTQ individuals have few legal protections against discrimination in housing. The Fair Housing Act prohibits discrimination on the basis of a number of protected characteristics, including sex, but does not include sexual orientation or gender identity. ${ }^{20}$ Members of Congress have tried, unsuccessfully, to amend the statute to include these characteristics. ${ }^{21}$ After the Obergefell v. Hodges ${ }^{22}$ opinion legalized same-sex marriage, the Equality Act was introduced multiple times. ${ }^{23}$ The Equality Act would have provided federal protection for gay people in housing, among other areas. It was passed in the House in 2019 but died in committee once in

16. Id. at xiv.

17. David Schwegman, Rental Market Discrimination Against Same-Sex Couples: Evidence from a Pairwise-Matched Email Correspondence Test, 29 Hous. POL'y DEBATE 250, 251 (2019).

18. Robert Espinoza, Out \& Visible: The Experiences and Attitudes of Lesbian, Gay, Bisexual and Transgender Older Adults, Ages 45-75, SAGE 19 (2014), https://www.sageusa.org/wpcontent/uploads/2018/05/sageusa-out-visible-lgbt-market-research-full-report.pdf [https://perma.cc /JQ9J-ZBCK].

19. Opening Doors: An Investigation of Barriers to Senior Housing for Same-Sex Couples, EQUAL RTS. CTR. 5 (2014), https://equalrightscenter.org/wp-content/uploads/senior_housing report.pdf [https://perma.cc/9PTD-NHW6]. This was the case for the plaintiffs in Walsh v. Friendship Village, discussed infra Part II.B.

20. 42 U.S.C. $\$ 3604$.

21. See H.R. 1447, 115th Cong. (2017); S. 1328, 115th Cong. (2017).

22. 576 U.S. 644, 681 (2015).

23. S. 1858, 114th Cong. (2015); S. 788, 116th Cong. (2019). 
the Senate. ${ }^{24}$ More recently, the bipartisan Fair and Equal Housing Act was introduced in the House of Representatives and the Senate on April 30, 2019 and was referred to committee in the House on May 20, 2019. ${ }^{25}$ The Fair and Equal Housing Act would provide consistent and explicit non-discrimination protections for LGBTQ people in housing by adding "sexual orientation" and "gender identity" as protected characteristics under the Fair Housing Act. ${ }^{26}$ It has failed to make it out of committee in either chamber.

State laws offer an inadequate patchwork of protection. Only twentytwo22 states and the District of Columbia prohibit discrimination in housing based on both sexual orientation and gender identity. ${ }^{27}$ Another state, Wisconsin, bans discrimination in housing based on sexual orientation only. ${ }^{28}$ A number of municipalities prohibit housing discrimination based on sexual orientation and gender identity, but these protections are typically ineffective and carry little force. ${ }^{29}$

During the Obama administration, the Department of Housing and Urban Development (HUD) took a number of steps to increase protections for LGBTQ individuals in housing. In the summer of 2010, HUD issued a guidance document with respect to sexual orientation and gender identity complaints. ${ }^{30}$ A memorandum from the Assistant HUD Secretary for Fair Housing and Equal Opportunity (FHEO) to regional FHEO directors about implementing the guidance document recognized that the federal Fair Housing Act does not specifically address sexual orientation, gender identity, or gender expression. ${ }^{31}$ The memo nevertheless instructs HUD

24. German Lopez, The House Just Passed a Sweeping LGBTQ Rights Bill, Vox (May 17, 2019, 12:14 PM), https://www.vox.com/policy-and-politics/2019/5/17/18627771/equality-act-housecongress-lgbtq-rights-discrimination [https://perma.cc/K3QY-CXAA].

25. H.R. 2402, 116th Cong. (2019); S. 1246 116th Cong. (2019).

26. H.R. 2402; S. 1246.

27. Nondiscrimination Laws, MAP (Jan. 6, 2021), https://www.lgbtmap.org/equality-maps/ non_discrimination_laws [https://perma.cc/3CM3-ZKM2].

28. $I d$.

29. See generally Chad A. Readler, Local Government Anti-Discrimination Laws: Do They Make a Difference?, 31 U. MicH. J.L. REFORM 777, 783-88, 804, 812-13 (1998) (finding local ordinances are often poorly publicized, the Human Rights Commissions tasked with enforcing such ordinances are often poorly staffed, and that the remedies available to local agencies are often limited). Indeed, many local anti-discrimination ordinances do not allow a private right of action for victims of discrimination to sue for damages, instead relying on the municipal attorney to bring civil charges. $I d$. at 794-95. The maximum penalty in many cases is usually a small fine ( $\$ 500$ or less). Id. at 798 n. 159,800 n. 176 .

30. Dana Rudolph, HUD Clarifies LGBT Housing Discrimination Practices, KeEN NEws SERV. (July 7, 2010), https://keennewsservice.com/2010/07/07/hud-clarifies-lgbt-housing-discriminationprotections/ [https://perma.cc/P995-8PTT]. The 2010 guidance document has been removed from HUD's website.

31. Memorandum from the U.S. Dep't of Hous. \& Urb. Dev., on Assessing Complaints that 
offices to "thoroughly review" allegations of LGBTQ discrimination in order to determine if the claims can be jurisdictional with respect to any existing protected classes. ${ }^{32}$ In other words, HUD recognized that LGBTQ status was not expressly covered as a protected characteristic by the statute, but nonetheless encouraged agency officials to find ways the FHA could protect the complainant by tying the discrimination to other protected characteristics.

For example, if a man alleges that he is being evicted because he is gay and his landlord believes he will infect other tenants with HIV, then the allegation of discrimination may be jurisdictional under the Act based on disability because the man is regarded as having a disability, HIV/AIDS. Similarly, if a female prospective tenant is alleging discrimination by a landlord because she wears masculine clothes and engages in other physical expressions that are stereotypically male, then the allegation may be jurisdictional under the Act as discrimination based on sex. ${ }^{33}$

The memo instructs agencies to refer any complaints lacking jurisdiction to state and local entities who might have authority under state law or municipal ordinance to pursue such complaints, and to track all such complaints in a federal database. ${ }^{34}$ Furthermore, the accompanying press release also made clear that "new [agency] guidance treats gender identity discrimination ... as gender discrimination under the Fair Housing Act, and instructs HUD staff to inform individuals filing complaints . . .".35 This type of informal agency guidance does not carry the force of law akin to formal agency rulemaking, though courts can give deference to such guidance. $^{36}$

Involve Sexual Orientation, Gender Identity, and Gender Expression to FHEO Regional Directors (June 15, 2010), https://www.fhcci.org/wp-content/uploads/2011/12/HUD-Memo-on-LGBTdiscrimination-6-15-2010.pdf [https://perma.cc/DXP2-9WQT].

32. Id. at 1 (emphasis in original).

33. Id.

34. Id.

35. Press Release, U.S. Dep't of Hous. \& Urb. Dev., HUD Issues Guidance on LGBT Housing Discrimination Complaints (July 1, 2010), https://archives.hud.gov/ news/2010/pr10-139.cfm [https://perma.cc/5ULE-WVU5].

36. When reviewing agency action, courts apply competing levels of deference depending on the type of action at issue.

Interpretations such as those in opinion letters-like interpretations contained in policy statements, agency manuals, and enforcement guidelines, all of which lack the force of law-do not warrant Chevron-style deference.... Instead, interpretations contained in formats such as [those] are "entitled to respect,"... but only to the extent that those interpretations have the "power to persuade."

Christensen v. Harris Cnty., 529 U.S. 576, 587 (2000) (quoting Skidmore v. Swift \& Co., 323 U.S. $134,140(1944))$. 
On February 3, 2012, HUD published a final regulation, the Equal Access Rule, to implement a "policy to ensure that its core programs are open to all eligible individuals and families regardless of sexual orientation, gender identity, or marital status." 37 This new rule revised the eligibility requirements for HUD-assisted or insured housing to require that "such housing shall be made available without regard to actual or perceived sexual orientation, gender identity, or marital status." 38

In HUD's comments accompanying the Rule, HUD noted that "certain complaints from LGBT persons would be covered by the Fair Housing Act. . . . includ[ing] discrimination because of nonconformity with gender stereotypes." "39 HUD also stated that it may have jurisdiction to "process a complaint filed under the Fair Housing Act if an LGBT person obtains housing but then experiences discrimination in the form of sexual harassment." ${ }^{\prime 0}$ These measures failed, however, to have a significant impact on HUD's enforcement of the FHA outside of HUD-owned or insured properties. Only one court, in an unpublished opinion, found that this jurisdictional statement — narrowed as it was to gender stereotype and sexual harassment cases - was a permissible interpretation of the statute. ${ }^{41}$ And even that case denied the plaintiff's claim because it failed to fit into one of those categories. ${ }^{42}$ As this Article was being prepared for publication, however, HUD announced that it would take more dramatic steps to ensure that the FHA is enforced in a manner to protect LGBTQ individuals. $^{43}$

Without national statutory protection against housing discrimination, LGBTQ individuals were left to look to the courts for protection. Judicial treatment of their claims, however, was heavily dependent on how courts in their jurisdiction had treated similar claims of sexual orientation and gender identity discrimination in Title VII cases. As will be discussed in greater detail in Section III, courts hearing FHA cases tend to rely on Title

37. Equal Access to Housing in HUD Programs Regardless of Sexual Orientation or Gender Identity, 77 Fed. Reg. 5662-01, 5662 (Feb. 3, 2012).

38. Id. at 5674 .

39. Id. at 5666

40. Id.

41. Thomas v. Osegueda, No. 2:15-CV-0042-WMA, 2015 WL 3751994, at *4 (N.D. Ala. June 16,2015 ) ("Considering the deference due by the court to agency interpretations, HUD's narrow tailoring of jurisdiction for discrimination based on sexual orientation to protections for gender stereotyping in its interpretation of the FHA is a permissible reading of "sex."'). As will be discussed further in Section II, sexual harassment and sex-stereotyping cases were, for many years, the only types of cases the Supreme Court recognized in the Title VII context that could give rise to claims by LGBTQ individuals. See infra Section II.A.2.

42. Id. at *4-5.

43. See infra Section IV, notes 179-185 and accompanying text. 
VII cases for their analysis. Thus, the next Section will trace the development of Title VII protections against sexual orientation and gender identity discrimination and show how a similar-but much slowerevolution took place with FHA cases.

\section{JUDICIAL TREATMENT OF SEXUAL ORIENTATION AND GENDER IDENTITY DISCRIMINATION CLAIMS}

\section{A. Title VII}

Sexual orientation and gender identity are not specifically set forth among the protected characteristics in Title VII, which prohibits employment discrimination on the basis of race, color, national origin, religion, and sex. ${ }^{44}$ Nevertheless, a number of plaintiffs have brought cases under Title VII claiming they were harassed or discriminated against because of their sexual orientation or gender identity, arguing that such discrimination actually constitutes sex discrimination.

\section{Early Cases}

For decades, courts refused to hear claims of discrimination based on sexual orientation or gender identity, concluding that "sex discrimination" simply did not encompass discrimination on these other bases. Often, courts based this conclusion on the fact that when Congress passed Title VII it did not intend for the law to apply to sexual orientation or gender identity. This type of intent analysis can be described as "expectations intent," that is, the court looks at whether the legislature that passed the statute would have expected and intended for it to be used in this manner. ${ }^{45}$ For example, in Holloway v. Arthur Andersen \& Co. ${ }^{46}$ the court denied a transgender plaintiff's claim, writing:

\footnotetext{
44. 42 U.S.C. $\$ 2000 \mathrm{e}-2$.

45. While it is likely true that when Congress passed Title VII it was not thinking that "sex" might encompass sexual orientation and gender identity, it is also true that discerning congressional intent when it comes to the term "sex" is nearly impossible. The amendment adding "sex" was passed one day before the House of Representatives approved Title VII and nothing significant emerged from the limited floor discussion. Diaz v. Pan Am. World Airways Inc., 442 F.2d 385, 386-87 (5th Cir. 1971). The amendment was introduced by Representative Howard Smith of Virginia, who had opposed the Civil Rights Act, and was accused by some of wishing to sabotage its passage by his proposal of the "sex" amendment. Peter F. Ziegler, Note, Employer Dress and Appearance Codes and Title VII of the Civil Rights Act of 1964, 46 S. CAL. L. REV. 965, 968 (1973); Developments in the Law: Employment Discrimination and Title VII of the Civil Rights Act of 1964, 84 HARV. L. REV. 1109, 1167 (1971).

46. 566 F.2d 659 (9th Cir. 1977) overruled by Schwenk v. Hartford, 204 F.3d 1187 (9th Cir. 2000).
} 
The cases interpreting Title VII sex discrimination provisions agree that they were intended to place women on an equal footing with men. Giving the statute its plain meaning, this court concludes that Congress had only the traditional notions of "sex" in mind. ... Congress has not shown any intent other than to restrict the term "sex" to its traditional meaning. Therefore, this court will not expand Title VII's application in the absence of Congressional mandate. The manifest purpose of Title VII's prohibition against sex discrimination in employment is to ensure that men and women are treated equally, absent a bona fide relationship between the qualifications for the job and the person's sex. ${ }^{47}$

Later, DeSantis v. Pacific Telephone \& Telegraph Co. cited Holloway in denying claims brought by groups of gay and lesbian plaintiffs who argued that they had been harassed, discriminated against, and fired from their jobs because of their sexual orientation. Other courts pointed out that Congress must have intended a "traditional" interpretation of the word "sex" because it placed the term along with immutable characteristics (race, color, national origin) and a characteristic "so deeply rooted for most that it is almost immutable ([similar to] religion)." 48

Courts that denied claims by LGBTQ individuals were also careful to distinguish "sex" from "sexual orientation" and "gender identity." They interpreted the phrase "because of sex" to mean only that the discrimination had occurred because a person was male or female. ${ }^{49}$ For example, in Ulane v. Eastern Airlines, Inc., ${ }^{50}$ the Seventh Circuit ordered the trial court to dismiss a claim brought by a transgender woman who was fired from her job. Ulane stated that Title VII's prohibition against sex discrimination means only "that it is unlawful to discriminate against women because they are women and against men because they are men." 51 The court reasoned:

If Eastern had considered Ulane to be female and had discriminated against her because she was female (i.e., Eastern treated females less favorably than males), then the argument might be made that Title VII applied, ... but that is not this case. It is clear from the evidence that if

47. Id. at 662-63 (internal citations and footnotes omitted).

48. Dillon v. Frank, No. 90-2290, 1992 WL 5436, at *4 (6th Cir. Jan. 15, 1992); see also DeCintio v. Westchester Cnty. Med. Ctr., 807 F.2d 304, 306-07 (2d Cir. 1986) (citations omitted) ("The proscribed differentiation under Title VII, therefore, must be a distinction based on a person's sex, not on his or her sexual affiliations."); Willingham v. Macon Tel. Publ'g Co., 507 F.2d 1084, 1090 (5th Cir. 1975) ("Congress in all probability did not intend for its proscription of sexual discrimination to have significant and sweeping implications. We should not therefore extend the coverage of the Act to situations of questionable application without some stronger Congressional mandate.").

49. See cases cited supra note 48. This, of course, failed to consider gender nonbinary individuals.

50. 742 F.2d 1081, 1087 (7th Cir. 1984).

51. Id. at 1085 . 
Eastern did discriminate against Ulane, it was not because she is female, but because Ulane is a transsexual - a biological male who takes female hormones, cross-dresses, and has surgically altered parts of her body to make it appear to be female. ${ }^{52}$

\section{Supreme Court Nuance}

The arguments about congressional intent and textual analysis were complicated by two Supreme Court opinions, Oncale v. Sundowner Offshore Services, Inc. ${ }^{53}$ and Price Waterhouse v. Hopkins. ${ }^{54}$ Oncale addressed the issue of congressional intent. It involved a case of severe sexual harassment carried out in a workplace by a group of men against another man. ${ }^{55}$ Previous courts had ruled that Title VII's prohibition of discrimination "because of sex" could not apply to same-sex sexual harassment because this could not have been Congress's intent when it included "sex" as a protected characteristic in Title VII. ${ }^{56}$ Writing for a unanimous court, Justice Scalia rejected this argument. While he recognized that same-sex harassment was surely not the problem that Congress sought to address when it enacted Title VII, he also observed:

[S]tatutory prohibitions often go beyond the principal evil to cover reasonably comparable evils, and it is ultimately the provisions of our laws rather than the principal concerns of our legislators by which we are governed. Title VII prohibits "discriminat[ion] ... because of ... sex" in the "terms" or "conditions" of employment. Our holding that this includes sexual harassment must extend to sexual harassment of any kind that meets the statutory requirements. ${ }^{57}$

In other words, the Court determined that regardless of what Congress intended, the words "because of sex" can cover a situation in which a man was harassed in a sexual manner, even if it was by other men. In this sense, the Court was relying on "semantic intent," which is to say that it looked to the plain meaning of the words regardless of what Congress might have intended when it passed Title VII. The Court sought to clarify, noting that:

$[\mathrm{H}]$ arassing conduct need not be motivated by sexual desire to support

\footnotetext{
52. Id. at 1087.

53. 523 U.S. 75 (1998).

54. 490 U.S. 228 (1989) (plurality opinion).

55. Oncale, 523 U.S. at 77. It appears that all of the men involved - the assailants as well as the plaintiff-were heterosexual. Thus, the issue of sexual orientation was not raised. Id. at 79-81 (noting other courts find a claim actionable by someone of the same sex "only if the plaintiff can prove that the harasser is homosexual (and thus presumably motivated by sexual desire)").

56. Id. at 79-81.

57. Id. at 79-80 (alteration in original).
} 
an inference of discrimination on the basis of sex. A trier of fact might reasonably find such discrimination, for example, if a female victim is harassed in such sex-specific and derogatory terms by another woman as to make it clear that the harasser is motivated by general hostility to the presence of women in the workplace. ${ }^{58}$

Price Waterhouse complicated the textual argument about sex-based discrimination. In this case, the plaintiff's sex discrimination claim centered on the allegation that she was denied partnership at her accounting firm because the partners believed she was too aggressive (although aggressiveness was seen as a positive trait for male candidates). ${ }^{59}$ She also presented evidence that the partners did not think she looked or behaved in a "feminine" enough manner. ${ }^{60}$ Ultimately, she argued that these sentiments stemmed from sex-role stereotyping, specifically the belief that women should conform to sex-based expectations that they be pretty, demure, and compliant. ${ }^{61}$ A plurality of the Court found that discrimination based on sex-role stereotypes constituted discrimination "because of sex." 62 The plurality went on to clarify, noting:

As for the legal relevance of sex stereotyping, we are beyond the day when an employer could evaluate employees by assuming or insisting that they matched the stereotype associated with their group, for "[i]n forbidding employers to discriminate against individuals because of their sex, Congress intended to strike at the entire spectrum of disparate treatment of men and women resulting from sex stereotypes."

Both cases led to some degree of chaos for discrimination claims brought by LGBTQ individuals. After Oncale, courts struggled with the situation of same-sex sexual harassment where the victim was also gay or lesbian. Many took the position that while Title VII could cover same-sex harassment generally, the statute did not apply when the harassment was motivated by the plaintiff's sexual orientation. Thus, courts found themselves in the difficult position of trying to disentangle whether harassment of a sexual nature was directed at a person because of the

58. Id. at 80 .

59. Price Waterhouse, 490 U.S. at 234-35.

60. Id. at 235. The plaintiff, Ann Hopkins, was not a lesbian, and thus there was no discussion of sexual orientation.

61. Id. at 235-36.

62. Id. at 250 ("In the specific context of sex stereotyping, an employer who acts on the basis of a belief that a woman cannot be aggressive, or that she must not be, has acted on the basis of gender.").

63. Id. at 251 (alteration in original) (citing Los Angeles Dep't of Water \& Power v. Manhart, 425 U.S. 702,707 (1978)). 
person's sex, or because of their sexual orientation. ${ }^{64}$

Price Waterhouse similarly led to a situation where courts had to determine whether the bare fact of a person's homosexuality or transgender identity could serve as the basis for a sex discrimination claim using a sex stereotyping theory. ${ }^{65}$ In other words, does a lesbian automatically defy the sex-role stereotype that women should only be attracted to men? Similarly, does a transgender individual defy sex-role stereotyping, by definition, because of their identity with a sex other than the one they were assigned at birth?

Some courts permitted this sort of "bootstrap" argument, but others refused. For example, in Dawson v. Bumble \& Bumble, ${ }^{66}$ the court denied a plaintiff's claim, noting:

When utilized by an avowedly homosexual plaintiff, however, gender stereotyping claims can easily present problems for an adjudicator. This is for the simple reason that "[s]tereotypical notions about how men and women should behave will often necessarily blur into ideas about heterosexuality and homosexuality." Like other courts, we have therefore recognized that a gender stereotyping claim should not be used to "bootstrap protection for sexual orientation into Title VII."

Implicit in this reasoning was a refusal to recognize homosexuality itself as a failure to conform to sex-role stereotypes. Instead, courts would require plaintiffs to demonstrate that they were nonconforming in other ways, such as in behavior or appearance. ${ }^{68}$ For example, in Simonton $v$.

64. See Martin v. New York St. Dep't of Corr. Servs., 224 F. Supp. 2d 434, $446-47$ (N.D.N.Y. 2002); Trigg v. New York City Transit Auth., No. 99-CV-4730 (ILG), 2001 WL 868336, at *5-6 (E.D.N.Y. July 26, 2001) (rejecting plaintiff's claim because the plaintiff's "Amended Complaint is rife with references to sexual orientation, homophobia, and accusations of discrimination based on homosexuality."), aff'd, 50 Fed. App'x. 458 (2d Cir. 2002).

65. Mary Anne Case, Disaggregating Gender from Sex and Sexual Orientation: The Effeminate Man in the Law and Feminist Jurisprudence, 105 YALE L.J. 1, 17 (1995); Francisco Valdes, Queers, Sissies, Dykes, and Tomboys: Deconstructing the Conflation of "Sex," "Gender," and "Sexual Orientation" in Euro-American Law and Society, 83 CAL. L. REV. 1, 316 (1995) (noting that the courts seldom engaged in a principled application of sex stereotyping theory, and often refused to apply it to claims by LGBTQ individuals).

66. 398 F.3d 211 (2d Cir. 2005), overruled by Zarda v. Altitude Express, 883 F.3d 100 (2d Cir. 2018).

67. Id. at 218 (alteration in original) (internal citations omitted). See also Phipps v. Hous. Auth. of New Orleans, No. 15-3296, 2016 WL 164916, at *6 (E.D. La. Jan. 13, 2016) (internal quotations omitted) (quoting Vickers v. Fairfield Med. Ctr., 453 F.3d 757, 763-64 (6th Cir. 2006)) (“'AA] gender stereotyping claim should not be used to bootstrap protection for sexual orientation into Title VII. Without alleging facts that would support a sex stereotyping theory, this is precisely what the plaintiff is attempting to do.").

68. Kristin M. Bovalino, How the Effeminate Male Can Maximize His Odds of Winning Title VII Litigation, 53 SYRACUSE L. REV. 1117, 1134 (2003) (counseling "gay plaintiffs bringing claims under Title VII [to] emphasize the gender stereotyping theory and de-emphasize any connection the discrimination has to homosexuality."). 
Runyon, a gay postal worker alleged that he was subjected to an abusive and hostile work environment because of his sexual orientation. ${ }^{69}$ The court denied the plaintiff's gender stereotyping claim, noting:

Simonton has failed to plead sufficient facts for our consideration of the issue.... We do not have sufficient allegations before us to decide Simonton's claims based on stereotyping because we have no basis in the record to surmise that Simonton behaved in a stereotypically feminine manner and that the harassment he endured was, in fact, based on his non-conformity with gender norms instead of his sexual orientation. ${ }^{70}$

Thus, for many years the Price Waterhouse sex-stereotyping theory was the only way plaintiffs could succeed in bringing sexual orientation and gender identity claims. Even this theory would not always work, as some courts refused to allow bootstrapped claims where plaintiffs' only gender nonconforming behavior was their sexual orientation or gender identity. Oncale provided a narrow path for victims of same-sex harassment, but apparently only if the harassment was not based on the victim's sexual orientation.

\section{Shifting Judicial Attitudes}

Recent years, however, have seen a shift in judicial attitudes toward such claims as society's understanding of sexual orientation and gender identity have evolved. In a 2017 refusal to hire case, Hively v. Ivy Tech Community College, the Seventh Circuit, sitting en banc, offered multiple arguments to support its conclusion that Title VII prohibits discrimination based on sexual orientation. ${ }^{71}$ The simplest was the Price Waterhouse sexual stereotyping argument, in which the court upheld the plaintiff's

69. 232 F.3d 33, 34 (2d Cir. 2000).

70. Id. at 38 (internal citations omitted). See also Bibby v. Philadelphia Coca Cola Bottling Co., 260 F.3d 257, 264 (3d Cir. 2001) (determining that a gay male plaintiff had no claim under Title VII because "he did not claim that he was harassed because he failed to comply with societal stereotypes of how men ought to appear or behave"); Spearman v. Ford Motor Co., 231 F.3d 1080, 1085 (7th Cir. 2000) (finding that a gay male automobile worker was subjected to harassment by fellow employees because of sexual orientation, not because "co-workers perceived him to be too feminine to fit the male image at Ford."), overruled by Hively v. Ivy Tech Cmty. Coll. of Ind., 853 F.3d 339 (7th Cir. 2017) (en banc); $c f$. Kay v. Independence Blue Cross, No. CIV.A. 02-3157, 2003 WL 21197289, at *5 (E.D. Pa. May 16, 2003) (holding that gay male plaintiff "has shown that he was subjected to adverse treatment because [of] his co-workers["] perceptions that he was a 'miss prissy' or less than [a] 'real man.' As such, there is affirmative evidence that the harassment was related to perceptions about Mr. Kay's masculinity, rendering the conduct gender stereotyping actionable under Title VII."); but see Heller v. Columbia Edgewater Country Club, 195 F. Supp. 2d 1212, 1224 (D. Or. 2002) (noting that a lesbian plaintiff stated Title VII claim by alleging discrimination based upon her failure to conform to supervisor's "stereotype of how a woman ought to behave.").

71. 853 F.3d 339, 350-51 (7th Cir. 2017) (en banc). 
bootstrapped claim. ${ }^{72}$

Next, the court took on the contention that sex was textually distinct from sexual orientation. Previous courts had found no sex discrimination because gay men and lesbians were equally discriminated against. Hively rejected this argument, using what it referred to as "the tried-and-true comparative method." "73 This method required the court to isolate the significance of the plaintiff's sex to the employer's decision. ${ }^{74}$ The question, the court determined, was whether Hively had "described a situation in which, holding all other things constant and changing only her sex, she would have been treated the same way?"75

Other courts purported to use this method but had not upheld plaintiffs' claims. Their reasoning was that an employer's anti-gay discrimination affected men and women equally. Hively argued that this reasoning was flawed:

It is critical, in applying the comparative method, to be sure that only the variable of the plaintiff's sex is allowed to change. The fundamental question is not whether a lesbian is being treated better or worse than gay men, bisexuals, or transsexuals, because such a comparison shifts too many pieces at once. Framing the question that way swaps the critical characteristic (here, sex) for both the complainant and the comparator and thus obscures the key point-whether the complainant's protected characteristic played a role in the adverse employment decision. The counterfactual we must use is a situation in which Hively is a man, but everything else stays the same: in particular, the sex or gender of the partner. $^{76}$

Applying this analysis, the court concluded that the plaintiff's sexual orientation claim was based on sex, because if she had been a man who was attracted to women, she would have been treated differently. ${ }^{77}$

Finally, the court relied on a related associational theory, which had originally been used to address anti-miscegenation laws. ${ }^{78}$ As the court noted:

It is now accepted that a person who is discriminated against because of the protected characteristic of one with whom she associates is actually being disadvantaged because of her own traits. This line of cases began

72. Id. at 342-43 (finding no argument that the plaintiff, Kristen Hively, defied gender stereotypes in any way beyond the fact that she was a lesbian).

73. Id. at 345 .

74. Id.

75. Id.

76. Id.

77. Id. at 346

78. Id. at 347 . 
with Loving [v. Virginia], in which the Supreme Court held that "restricting the freedom to marry solely because of racial classifications violates the central meaning of the Equal Protection Clause." The Court rejected the argument that miscegenation statutes do not violate equal protection because they "punish equally both the white and the Negro participants in an interracial marriage." When dealing with a statute containing racial classifications, it wrote, "the fact of equal application does not immunize the statute from the very heavy burden of justification" required by the Fourteenth Amendment for lines drawn by race.

.... The Court in Loving recognized that equal application of a law that prohibited conduct only between members of different races did not save it. Changing the race of one partner made a difference in determining the legality of the conduct, and so the law rested on "distinctions drawn according to race," which were unjustifiable and racially discriminatory. So too, here. If we were to change the sex of one partner in a lesbian relationship, the outcome would be different. This reveals that the discrimination rests on distinctions drawn according to sex. ${ }^{79}$

Thus, the Seventh Circuit became the first federal court of appeals to recognize that sex discrimination, by its nature, encompasses sexual orientation discrimination without relying on a sex stereotyping theory.

Courts have evolved in a similar way when it comes to gender identity and Title VII. In Schroer v. Billington,${ }^{80}$ the District Court for the District of Columbia held that discrimination against a transgender woman violated Title VII. The court first upheld the plaintiff's claim under a Price Waterhouse sex-stereotyping theory. ${ }^{81}$ It went on to hold as a textual matter that gender identity discrimination is per se sex discrimination, as it necessarily involves consideration of both biological sex and gender, which is a key component of sex. ${ }^{82}$

Schroer concluded that courts which had refused to recognize gender identity discrimination as sex discrimination had allowed their views of congressional intent to blind themselves to the plain language of the statute: ${ }^{83}$

79. Id. at 347-49 (internal citations omitted).

80. 577 F. Supp. 2d 293, 308 (D.D.C. 2008).

81. Id. at $305-06$.

82. Id. at 308 ("[T] he Library's refusal to hire Schroer after being advised that she planned to change her anatomical sex by undergoing sex reassignment surgery was literally discrimination 'because of ... sex."'). As one commentator noted, "[S]ince [Schroer's] goal was not to transgress stereotypes, but to adopt an entirely new gender and conform to its stereotypes, Price Waterhouse did not apply." Michael J. Vargas, Title VII and the Trans-Inclusive Paradigm, 32 LAW \& INEQ. 169, 191 (2014).

83. Schroer, 577 F. Supp. 2d at 307 ("In other words, courts have allowed their focus on the label 'transsexual' to blind them to the statutory language itself."). 
The decisions [such as Ulane] holding that Title VII only prohibits discrimination against men because they are men, and discrimination against women because they are women, represent an elevation of "judge-supposed legislative intent over clear statutory text." [Courts which hold] that discrimination based on changing one's sex is not discrimination because of sex ... essentially reason "that a thing may be within the letter of the statute and yet not within the statute, because not within its spirit, nor within the intention of its makers." This is no longer a tenable approach to statutory construction. Supreme Court decisions [such as Oncale] have applied Title VII in ways Congress could not have contemplated. ${ }^{84}$

\section{B. FHA Cases}

Sexual orientation and gender identity claims brought under the FHA have followed a similar trajectory. As with the early Title VII cases, the first courts to hear FHA claims of sexual orientation and gender identity discrimination dismissed them out of hand, often with little analysis. ${ }^{85}$

One recent example of a court's dismissal came in Walsh v. Friendship Village of South County. ${ }^{86}$ In that case, the plaintiffs, Mary Walsh and Beverly Nance, were an older, married couple who had been in a committed relationship for nearly forty years. ${ }^{87}$ They wished to move to a senior living community, and were particularly interested in a community called Friendship Village, in St. Louis County, Missouri. ${ }^{88}$ After multiple visits and discussions with the community's Residence Director, Carmen Fronczak, the couple submitted a \$2,000 deposit and signed a waitlist agreement. ${ }^{89}$ A few days later, Ms. Fronczak called Ms. Walsh to inquire about the nature of her relationship with Ms. Nance, to which Ms. Walsh replied that they were married. ${ }^{90}$ Two days later, Ms. Fronczak called Ms. Walsh to inform her that Friendship Village's Cohabitation Policy did not permit the plaintiffs to share a single residency unit. ${ }^{91}$

Ms. Walsh later received a letter from the Corporate Operations

84. Id. (internal citations omitted).

85. See Miller v. 270 Empire Realty LLC, No. 09-CV-2857 (RJD)(RER), 2012 WL 1933798, *5-6 (E.D.N.Y. Apr. 6, 2012), report and recommendation adopted, No. 09-CV-2857 (RJD)(RER), 2012 WL 1940829, *1 (E.D.N.Y. May 29, 2012) (holding FHA claims cannot be based on sexual orientation); Swinton v. Fazekas, No. 06-CV-6139T, 2008 WL 723914, *5 (W.D.N.Y. Mar. 14, 2008).

86. 352 F. Supp. 3d 920 (E.D. Mo. 2019), vacated and remanded by 2020 WL 5361010, (8th Cir., July 2, 2020) (in light of Bostock v. Clayton Cnty., No. 17-1618, 2020 WL 3146686 (U.S. June $15,2020)$ ).

87. Id. at 922 .

88. Id. at 923 .

89. Id.

90. Id.

91. Id. 
Director of Friendship Village, which stated, "[y]our request to share a single unit does not fall within the categories permitted by the longstanding policy of Friendship Village Sunset Hills, a copy of which is enclosed." ${ }^{92}$ The Friendship Village Cohabitation Policy, attached to the letter, noted:

It is the policy of Friendship Village . . . consistent with its long-standing practice of operating its facilities in accordance with biblical principles and sincerely-held religious standards, that it will permit the cohabitation of residents within a single unit only if those residents, while residing in said unit, are related as spouses by marriage, as parent and child or as siblings. The term "marriage" as used in this policy means the union of one man and one woman, as marriage is understood in the Bible. . . 93

Walsh and Nance filed an FHA suit against Friendship Village. They made a bootstrapped Price Waterhouse argument, claiming Friendship Village discriminated against them on the basis of sex, because of their nonconformity with sex stereotypes, "including that a married woman should be in a different-sex relationship; that a married woman's spouse should be a man; and that women should be attracted to and form relationships with men, not women."94 Walsh and Nance also argued that sexual orientation discrimination was discrimination based on sex, and that they had each been discriminated against because of their association with a person of a particular sex..$^{95}$

Looking to employment law cases, the court rejected the plaintiffs' sex stereotyping claim. It determined that it "need not struggle with exactly where to draw the line between actionable discrimination based on what is alleged to be gender non-conforming behavior and non-actionable discrimination based on sexual orientation." 96 According to the court, the plaintiffs failed to present an actionable claim because they made clear that their theory of sex-stereotyping was based solely on their sexual orientation. "Sexual orientation alone cannot be the alleged gender nonconforming behavior that gives rise to an actionable Title VII claim under a sex-stereotyping theory," the court held, because "[t]o hold otherwise would be contrary to well-settled law that Title VII does not prohibit discrimination on the basis of sexual orientation." 97

\footnotetext{
92. Id.

93. Id.

94. Id. at 924 .

95. Id. at $924-26$.

96. Id. at 927 (quoting Pambianchi v. Arkansas Tech Univ., No. 4:13-cv-00046-KGB, 2014 WL 11498236, at*5 (E.D. Ark. Mar. 14, 2014)).

97. Id. at 927 (quoting Pambianchi, 2014 WL 11498236, at *5); see also Thomas v. Osegueda,
} 
The court engaged in a rudimentary comparative analysis, one that suffered from the same analytical flaw the Hively court had observed:

At no time do Plaintiffs assert that had they been men involved in a samesex relationship or marriage, they would have been admitted as residents in Friendship Village. Under these circumstances, the Court finds the claims boil down to those of discrimination based on sexual orientation rather than sex alone. ${ }^{98}$

The court similarly dismissed the plaintiffs' related associational claim. Instead of recognizing the claim as one made by a woman who had been discriminated against for associating with another woman (thus making sex the relevant discriminatory category), the court appeared to treat the claim as one by a lesbian who wished to associate with another lesbian (thus making sexual orientation the relevant discriminatory category):

While the Court agrees that claims of associational discrimination are cognizable at times, Plaintiffs present no evidence that such claims are actionable with respect to classes unprotected by the statute at issue. As noted above, sexual orientation is one such unprotected class, and so this portion of Defendants' motion must be granted. ${ }^{99}$

The few courts to uphold sexual orientation and gender identity claims did so using the Price Waterhouse sex-stereotyping theory. Smith $v$. Avanti $^{100}$ is a rare example of such a case. Rachel and Tonya Smith are a married lesbian couple living in Colorado with their two children. ${ }^{101}$ Rachel is also a transgender woman. ${ }^{102}$ When they sought to rent a townhouse for their family, Tonya disclosed Rachel's transgender status to the current property owner. ${ }^{103}$ The property owner then requested photos of the family and held an in-person meeting with them. ${ }^{104}$ At this

No. 2:15-CV-0042-WMA, 2015 WL 3751994, at *4 (N.D. Ala. June 16, 2015) ("Thomas does not petition under a theory of gender non-conformity but rather relies on sexual orientation as the sole basis for discrimination separate and independent of gender.... Even under HUD's expanded interpretation of the FHA for gender stereotyping, these allegations are outside the scope of the FHA's 'sex' discrimination protection and therefore HUD lacks the jurisdiction for respondents to act upon them.").

98. Walsh, 352 F. Supp. 3d at 925-26.

99. Id. at 927. In February 2019, the plaintiffs filed an appeal with the U.S. Court of Appeals for the Eighth Circuit. The Eighth Circuit put the appeal on hold pending the Supreme Court's decision in Bostock v. Clayton County, and subsequently vacated the District Court's opinion and remanded the case. See supra note 86.

100. 249 F. Supp. 3d 1194 (D. Colo. 2017).

101. Id. at 1197 .

102. Id.

103. Id.

104. Id. 
meeting, the owner refused to rent to them, suggesting the Smiths" "unique relationship" and "uniqueness" would become the town focus and would jeopardize the property owner's "low profile" in the community. ${ }^{105}$

The Smiths then filed suit, proceeding on a sex stereotyping theory, by arguing that discrimination against a lesbian couple "for failure to conform to stereotyp[ical] norms concerning to or with whom a woman should be attracted, should marry, and/or should have children is discrimination on the basis of sex under the FHA." 106 The court agreed with them, citing Price Waterhouse: "Such stereotypical norms are no different from other stereotypes associated with women, such as the way she should dress or act (e.g., that a woman should not be overly aggressive, or should not act macho), and are products of sex stereotyping."107

Next, the Smiths argued that discrimination against a transgender person because of her gender-nonconformity is a form of sex discrimination. The court looked to Title VII, observing that:

The Tenth Circuit looks to Title VII discrimination cases for guidance in addressing discrimination issues under the FHA.... [D]iscrimination against a transsexual based on the person's status as a transsexual is not discrimination because of sex under Title VII. However, the Smiths' sex discrimination claim at issue is brought on the basis of gender stereotyping under Price Waterhouse v. Hopkins . . . and its progeny, and recognized as a possibility by the Tenth Circuit . . . ${ }^{108}$

In light of this guidance, the court agreed with the Smiths on a narrow basis: "To the extent the Smiths contend that discrimination against Rachel because she does not conform to gender norms of a male, e.g., does not act or dress like the stereotypical notions of a male, the Court agrees." 109 The court, however, refused to allow the argument to go any further. In a somewhat muddled analysis, it rejected the notion that discrimination against a person solely on the basis of transgender identity or sexual orientation could constitute a sex stereotyping violation, or that such discrimination was per se sex-based discrimination. "To the extent Plaintiffs are attempting to bootstrap such other theories onto their sex stereotype theory," the court stated, it would not accept such a leap. ${ }^{110}$

Despite the Avanti court's protestations, its decision came vanishingly close to recognizing a bootstrapped theory for both sexual orientation and

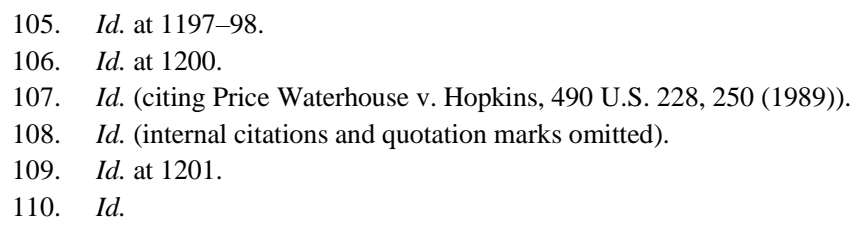


gender identity claims. In essence, it held that if a defendant discriminates against a gay couple because their sexual orientation defies sex stereotypes, such a claim is actionable. Similarly, it held that discrimination against a transgender person could be actionable so long as this discrimination was based on failure to conform to gender stereotypes. Of course, it is difficult to see how either of these types of discrimination do not always rest in some degree on sex stereotypes, but the court, perhaps in fear of violating Tenth Circuit precedent, was unwilling to state this explicitly.

\section{The Supreme Court Opinion in Bostock v. Clayton County}

The issue of whether Title VII covers discrimination based on sexual orientation and gender identity came before the Supreme Court in three different cases which were litigated separately but consolidated for purposes of the Supreme Court proceedings. In Bostock v. Clayton County Board of Commissioners, the Eleventh Circuit upheld the dismissal of a gay man's Title VII claim, holding summarily that "[d]ischarge for homosexuality is not prohibited by Title VII." 111 In Zarda v. Altitude Express, Inc., the Second Circuit, sitting en banc, held that a gay man could bring a claim under Title VII alleging that he was fired due to his sexual orientation. ${ }^{12}$ Similarly, EEOC v. R.G. \& G.R. Harris Funeral Homes, Inc. involved a transgender woman who was fired from her job. ${ }^{113}$ Here, the Sixth Circuit noted that "[b]ecause an employer cannot discriminate against an employee for being transgender without considering that employee's biological sex, discrimination on the basis of transgender status necessarily entails discrimination on the basis of sexno matter what sex the employee was born or wishes to be."114

The arguments made by the defendants in Harris Funeral Homes were the same as those in previous cases: (1) that textually, discrimination based on sexual orientation and gender identity is not the same thing as discrimination based on sex because each targets something more than just a person's sex, and (2) that sexual orientation or gender identity could not be covered by Title VII because Congress did not intend for those to be protected characteristics. ${ }^{115}$ The Bostock majority, in an opinion authored

111. 723 F. App’x 964, 964 (11th Cir. 2018) (alteration in original) (quoting Blum v. Gulf Oil Corp., 597 F.2d 936, 938 (5th Cir. 1979)), cert. granted, 139 S. Ct. 1599, (2019), rev'd and remanded by, 140 S. Ct. 1731, (2020).

112. 883 F.3d 100, 132 (2d Cir. 2018).

113. 884 F.3d 560, 566 (6th Cir. 2018).

114. Id. at 578 .

115. Id. at $577-78$. 
by Justice Gorsuch, squarely rejected these arguments. ${ }^{116}$

From a textual standpoint, Gorsuch relied on the type of comparative argument that prevailed in Hively. The Bostock opinion clarified that sex is inseparable from sexual orientation and gender identity:

[I]t is impossible to discriminate against a person for being homosexual or transgender without discriminating against that individual based on sex. Consider, for example, an employer with two employees, both of whom are attracted to men. The two individuals are, to the employer's mind, materially identical in all respects, except that one is a man and the other a woman. If the employer fires the male employee for no reason other than the fact he is attracted to men, the employer discriminates against him for traits or actions it tolerates in his female colleague. Put differently, the employer intentionally singles out an employee to fire based in part on the employee's sex, and the affected employee's sex is a but-for cause of his discharge. Or take an employer who fires a transgender person who was identified as a male at birth but who now identifies as a female. If the employer retains an otherwise identical employee who was identified as female at birth, the employer intentionally penalizes a person identified as male at birth for traits or actions that it tolerates in an employee identified as female at birth. Again, the individual employee's sex plays an unmistakable and impermissible role in the discharge decision. ${ }^{117}$

The majority also rejected the defense based on congressional intent. It recognized and rejected the expectations-based argument that the plaintiffs' claims should fail because Congress likely did not anticipate Title VII being used to protect individuals from sexual orientation and gender identity discrimination in this particular way. The text, it found, clearly supported the plaintiffs' interpretation:

Rather than suggesting that the statutory language bears some other meaning, the employers and dissents merely suggest that, because few in 1964 expected today's result, we should not dare to admit that it follows ineluctably from the statutory text. When a new application emerges that is both unexpected and important, they would seemingly have us merely point out the question, refer the subject back to Congress, and decline to enforce the plain terms of the law in the meantime.

That is exactly the sort of reasoning this Court has long rejected. Admittedly, the employers take pains to couch their argument in terms of seeking to honor the statute's "expected applications" rather than vindicate its "legislative intent." But the concepts are closely related. One could easily contend that legislators only intended expected applications or that a statute's purpose is limited to achieving

116. Bostock v. Clayton Cnty. Bd. of Comm'rs, 140 S. Ct. 1731, 1738-41 (2020).

117. Id. at 1741-42. 
applications foreseen at the time of enactment. However framed, the employer's logic impermissibly seeks to displace the plain meaning of the law in favor of something lying beyond it. ${ }^{118}$

The Court went even further, recognizing that Congress deliberately drafted Title VII using broad and sweeping language, and thus, it must have intended for the law to apply in a variety of unexpected scenarios:

Title VII's prohibition of sex discrimination in employment is a major piece of federal civil rights legislation. It is written in starkly broad terms. It has repeatedly produced unexpected applications, at least in the view of those on the receiving end of them. Congress's key drafting choices - to focus on discrimination against individuals and not merely between groups and to hold employers liable whenever sex is a but-for cause of the plaintiff 's injuries - virtually guaranteed that unexpected applications would emerge over time. ${ }^{119}$

In this sense, the Court relied on a view of congressional intent that looked beyond the plain language of the statute (the semantic view) to the purpose of the statute. In other words, the Court considered the normative principles and goals underlying Title VII, rather than focusing solely on the statute's text.

\section{What Bostock MEANs For THE FAIR HOUSING ACT}

Bostock established that Title VII's "because of sex" language applies to discrimination based on sexual orientation and gender identity. The obvious next question is whether and to what extent this analysis should apply to the FHA's identical language. As discussed previously, when courts hear cases under the Fair Housing Act, they often look to Title VII case law for guidance. This makes sense for a number of reasons. Both statutes are remedial civil rights laws, passed within a few years of each other. Both also follow a similar structure and, in a number of places, they contain identical or very similar language. ${ }^{120}$ The Supreme Court previously clarified that "when Congress uses the same language in two statutes having similar purposes, particularly when one is enacted shortly after the other, it is appropriate to presume that Congress intended that text

\footnotetext{
118. Id. at 1750 .

119. Id. at 1753 .

120. Texas Dep't of Hous. \& Cmty. Affs. v. Inclusive Cmtys. Project, Inc., 576 U.S. 519, 530 33 (2015) (comparing $§ 3604$ (a) of the FHA to Title VII); Bloch v. Frischholz, 587 F.3d 771, 779 (7th Cir. 2009) (noting that $\S 3604$ (b) of the FHA mirrors Title VII); Kyles v. J.K. Guardian Sec. Servs., Inc., 222 F.3d 289, 295 (7th Cir. 2000) (citations omitted) (describing Title VII and the FHA as "functional equivalent[s]" to be "given like construction and application.").
} 
to have the same meaning in both statutes."121

Indeed, in another recent case, Texas Department of Housing and Community Affairs v. The Inclusive Communities Project, Inc., the Supreme Court relied heavily on its Title VII jurisprudence in interpreting the FHA. Specifically, the Court addressed whether plaintiffs could assert discrimination claims using disparate impact theory under the FHA. ${ }^{122}$ This theory allows a plaintiff to bring a claim based on the adverse impact of a defendant's actions, without arguing that these actions were intentionally discriminatory. ${ }^{123}$ The Supreme Court originally recognized disparate impact theory in an employment discrimination case, Griggs $v$. Duke Power Company, ${ }^{124}$ and Congress subsequently codified this decision in the 1991 amendments to Title VII. ${ }^{125}$ Congress did not, however, amend the FHA in a similar manner.

In Inclusive Communities, the Court examined the same "because of. ." language that appears in both Title VII and the FHA. In Griggs, the Court determined that an adverse action could be taken "because of" a protected characteristic even if the action was not intentionally discriminatory. ${ }^{126}$ Looking to the similar language, structure, and purpose of the two statutes, the Court determined that the "because of" analysis in Griggs should apply equally to the FHA, which would allow housing plaintiffs to bring disparate impact claims. ${ }^{127}$

The Court recognized that differences between the employment and housing contexts might affect how the affirmative defense to disparate impact claims would operate. Specifically, the "business necessity" defense available to employers faced with disparate impact claims, does not translate perfectly to the housing context. ${ }^{128}$ While an employer's business needs are probably somewhat straightforward, developers and municipalities may have multiple legitimate and competing factors to consider when making decisions about the siting and zoning of housing. ${ }^{129}$

\footnotetext{
121. Smith v. City of Jackson, 544 U.S. 228, 233 (2005). See Inclusive Cmtys., 576 U.S. at 535 ("This similarity in text and structure is all the more compelling given that Congress passed the FHA in 1968 —only four years after passing Title VII ....").

122. Inclusive Cmtys., 576 U.S. at 524-27.

123. Id.

124. 401 U.S. 424, 431-33 (1971) (invalidating a hiring practice, even in the absence of discriminatory intent, because of its disparate impact on black applicants).

125. 42 U.S.C. $\S 2000 \mathrm{e}-2(\mathrm{k})(1)(\mathrm{A})-(\mathrm{C})$.

126. Griggs, 401 U.S. at 432.

127. Inclusive Cmtys., 576 U.S. at 546.

128. Id. at 541 .

129. Id. at 541-42 ("Entrepreneurs must be given latitude to consider market factors. Zoning officials, moreover, must often make decisions based on a mix of factors, both objective (such as cost and traffic patterns) and, at least to some extent, subjective (such as preserving historic architecture).
} 
The Court, however, found that this difference was not salient enough to prevent the Title VII analysis from applying to this aspect of the FHA. ${ }^{130}$

At times, the courts' reliance on Title VII precedent has been more complicated, particularly when there are relevant differences between the housing and employment contexts. One example of this is in the area of sexual harassment. Courts first developed the law of sexual harassment in the employment context. Thus, when housing harassment cases started making their way through the court system roughly a decade later, all courts had to rely on was Title VII precedent. ${ }^{131}$ As commentators noted:

Indeed, the law of sexual harassment in housing developed well after and in virtual lock-step with the law of sexual harassment in employment. Thus, courts have simply interpreted the Fair Housing Act (FHA) to prohibit sexual harassment to the same degree - and only to the same degree - as it is prohibited in employment by Title VII of the 1964 Civil Rights Act. ${ }^{132}$

On one hand, this was helpful for advocates. The existence of a framework for analysis of sexual harassment claims under Title VII made it much easier for housing plaintiffs to assert those claims under the FHA. To that extent, the courts' use of Title VII precedent was beneficial and appropriate. On the other hand, there were problems with applying the framework. When federal courts developed the case law of hostile work environment sexual harassment for Title VII cases, they created a threshold standard for actionable claims. ${ }^{133}$ Thus, a plaintiff alleging hostile work environment sexual harassment could only prevail if she could show that the harassment she experienced was "severe or pervasive," so as to "alter the terms or conditions of the victim's employment." 134 The application of this rather imprecise standard became the key issue in many Title VII sexual harassment cases, with courts having to decide whether specific acts or statements in the workplace

These factors contribute to a community's quality of life and are legitimate concerns for housing authorities. The FHA does not decree a particular vision of urban development; and it does not put housing authorities and private developers in a double bind of liability, subject to suit whether they choose to rejuvenate a city core or to promote new low-income housing in suburban communities.").

130. Id. at 541 ("To be sure, the Title VII framework may not transfer exactly to the fair-housing context, but the comparison suffices for present purposes.").

131. The first court to hear a case of sexual harassment in housing relied exclusively on Title VII precedent. See Shellhammer v. Lewallen, No. C 82-689 II 15,472 (W.D. Ohio Nov. 22, 1983), aff'd, 770 F.2d 167 (6th Cir. 1985). Later cases followed suit. See DiCenso v. Cisneros, 96 F.3d 1004, 1005 (7th Cir. 1996); Honce v. Vigil, 1 F.3d 1085, 1087-88 (10th Cir. 1993); Beliveau v. Caras, 873 F. Supp. 1393, 1394-97 (C.D. Cal. 1995).

132. Robert G. Schwemm \& Rigel C. Oliveri, A New Look at Sexual Harassment Under the Fair Housing Act: The Forgotten Role of $\$ 3604(c), 2002$ WIS. L. REV. 771, 773 (2002) (footnotes omitted).

133. Meritor Sav. Bank, FSB v. Vinson, 477 U.S. 57, 66-67 (1986).

134. Id. (citing Henson v. City of Dundee, 682 F.2d 897, 904 (11th Cir. 1982)). 
cleared this threshold.

Courts hearing housing harassment cases looked to employment cases involving similar conduct, even though the workplace and the home are very different contexts. For example, "conduct that may appear harmless or less offensive in the workplace can become much more threatening when committed inside a woman's home by someone who literally holds the keys." ${ }^{135}$ Unfortunately, because courts were using employment precedent to inform their decisions in housing cases, they were reaching decisions that "many in the legal and academic world view[ed] as incorrect." 136 Other commenters noted:

[R]eliance on Title VII is inappropriate in FHA cases because the housing context makes sexual harassment there worse than in the workplace. The gist of this argument is that one's home should be a special place of privacy and sanctuary and should be more protected from an outsider's unwelcome intrusions than less sacrosanct locales such as the workplace. In addition, a harassing landlord is seen as more threatening than a job supervisor, both because a landlord has virtually unlimited access to his potential victims at any time and because the unequal power relationship that is inherent in harassment cases is generally more pronounced in a landlord-tenant situation than in an employment setting. This latter consideration is underscored by the fact that most reported cases of sexual harassment in housing have involved low-income women whose need for the housing controlled by their harasser is even more desperate than their counterparts' need for a job in most workplace harassment cases. ${ }^{137}$

Thus, even though the language prohibiting discrimination "based on sex" in Title VII and the FHA is identical, and the same "severe or pervasive" standard applies to hostile environment sexual harassment under both statutes, the differences in context between the workplace and the home justify applying the "severe or pervasive" standard differently. In other words, there are relevant factual differences between the two contexts which make Title VII precedent less helpful in certain sexual

135. Rigel C. Oliveri, Sexual Harassment of Low-Income Women in Housing: Pilot Study Results, 83 Mo. L. Rev. 597, 605 (2018) (footnote omitted); see also, Nicole A. Forkenbrock Lindemyer, Sexual Harassment on the Second Shift: The Misfit Application of Title VII Employment Standards to Title VIII Housing Cases, 18 LAW \& INEQ. 351, 352-53 (2000); Michelle Adams, Knowing Your Place: Theorizing Sexual Harassment at Home, 40 ARIZ. L. REV. 17, 21 (1998) (" $[S]$ exual harassment at home differs in context; a context that is reflected in the richness and complexity of our notions of home and women's roles within that home."); Deborah Zalesne, The Intersection of Socioeconomic Class and Gender in Hostile Housing Environment Claims Under Title VIII: Who Is the Reasonable Person?, 38 B.C. L. REV. 861, 885 (1997) ("Because of some fundamental differences... serious problems can arise if courts too closely equate the effects of workplace sexual harassment with the effects of rental housing sexual harassment.").

136. Oliveri, supra note 135, at 606 (footnote omitted).

137. Schwemm \& Oliveri, supra note 132, at 786-87 (footnotes omitted). 
harassment cases (even though courts were correct to base sexual harassment in housing claims on Title VII precedent, generally).

It also would be inappropriate for a court to rely wholesale on Title VII to interpret a FHA case when there are relevant differences in underlying legal doctrines between the two statutes. For example, in Wetzel v. Glen St. Andrew Living Community, $L L C^{138}$ the Seventh Circuit was asked to apply a Title VII standard to an FHA case and instead took a more cautious approach. The case was brought by a woman who alleged that she was severely harassed by fellow residents of a senior living community because she was a lesbian. ${ }^{139}$ The Seventh Circuit reversed the lower court's dismissal and recognized that well-established Title VII and FHA precedents allowed the plaintiff to bring such a claim. ${ }^{140}$ The more difficult question was how to define the standard of landlord liability for tenant-on-tenant harassment. The plaintiff asked the court to apply the Title VII standard of employer liability for employee-on-employee harassment, but the court declined:

We recognize, however, that there are some potentially important differences between the relationship that exists between an employer and an employee, in which one is the agent of the other, and that between a landlord and a tenant, in which the tenant is largely independent of the landlord. We thus refrain from reflexively adopting the Title VII standard and continue our search for comparable situations. ${ }^{141}$

In the Wetzel case, differences in context actually created different legal obligations. Thus, a wholesale reliance on Title VII was inappropriate, even as the court used Title VII to support the basic framework analysis for the claim.

In contrast, there is no reason why Bostock's interpretation of "because of sex" in Title VII to include claims of discrimination based on sexual orientation or gender identity should not apply equally to the FHA. ${ }^{142}$ There is no relevant contextual difference to support a distinction,

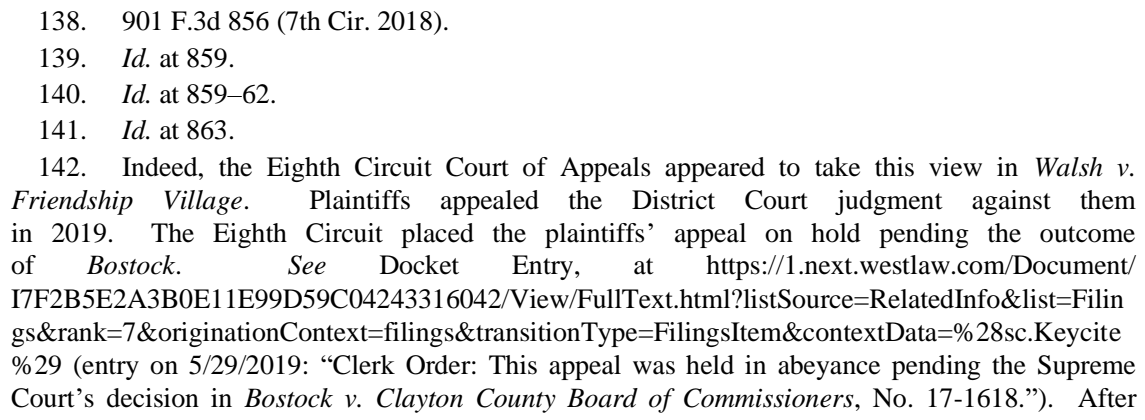


either as a factual or a legal matter, nor is there any policy justification or historical reason to do so. The similarities in the language, structure, and purpose of Title VII and the FHA support the application of Bostock's reasoning to the housing context.

As Justice Gorsuch argued in Bostock:

Title VII's prohibition of sex discrimination in employment is a major piece of federal civil rights legislation. It is written in starkly broad terms. It has repeatedly produced unexpected applications, at least in the view of those on the receiving end of them. Congress's key drafting choices - to focus on discrimination against individuals and not merely between groups and to hold employers liable whenever sex is a but-for cause of the plaintiff's injuries - virtually guaranteed that unexpected applications would emerge over time. ${ }^{143}$

All of these observations about Title VII are equally true about the FHA. Courts repeatedly invoke the FHA's stated purpose, "to provide .... for fair housing throughout the United States"144 to justify a generous interpretation and broad application of the statute. ${ }^{145}$ This includes allowing novel theories of discrimination and protections for people who Congress might not have originally intended to be beneficiaries of the statute.

The clearest example of this is the Supreme Court's first fair housing case, Trafficante v. Metropolitan Life Insurance Co., in which a white tenant in a housing complex sought to challenge his landlord's racially exclusionary practices. ${ }^{146}$ The plaintiff claimed he was deprived of the benefits of living in a racially-integrated environment and had suffered embarrassment from being "stigmatized" as a resident of a "white

Bostock was decided, the Eighth Circuit vacated the judgment of the district court and remanded the case for further proceedings in light of the opinion. Walsh v. Friendship Village of South County, No. 19-1395, 2020 WL 5361010, at*1 (8th Cir. July 2, 2020). In December 2020, the case was settled for an undisclosed sum. See Shahla Farzan, Same-Sex Couple Settle Housing Discrimination Lawsuit Against St. Louis Retirement Community, ST. LouIS PUB. RADIO (Dec. 9, 2020), https://news.stlpublicradio.org/government-politics-issues/2020-12-09/same-sex-couple-settle-housi ng-discrimination-lawsuit-against-st-louis-retirement-community [https://perma.cc/FJ3C-VYJQ].

143. Bostock v. Clayton Cnty., 140 S. Ct. 1731, 1753 (2020).

144. 42 U.S.C. $\$ 3601$.

145. Cases citing this provision in support of broadly construing the Fair Housing Act include: City of Edmonds v. Oxford House, Inc., 514 U.S. 725, 731 (1995); Revock v. Cowpet Bay W. Condo. Ass'n, 853 F.3d 96, 104-05 (3d Cir. 2017); Hunt v. Aimco Props., L.P., 814 F.3d 1213, 1223 (11th Cir. 2016); Connecticut Fair Hous. Ctr. v. Corelogic Rental Prop. Sols., LLC, 369 F. Supp. 3d 362, 370 (D. Conn. 2019); S \& R Dev. Ests., LLC v. Town of Greenburgh, 336 F. Supp. 3d 300, 310-11 (S.D.N.Y. 2018); Guider v. Bauer, 865 F. Supp. 492, 495 (N.D. Ill. 1994); Stackhouse v. DeSitter, 620 F. Supp. 208, 210-11 (N.D. Ill. 1985); United States v. Hughes Mem'l Home, 396 F. Supp. 544, 548 (W.D. Va. 1975); Zuch v. Hussey, 394 F. Supp. 1028, 1046 (E.D. Mich. 1975), aff'd, 547 F.2d 1168 (6th Cir. 1977); United States v. Real Est. Dev. Corp., 347 F. Supp. 776, 781 (N.D. Miss. 1972).

146. 409 U.S. 205, 206-07 (1972). 
ghetto."147 The district court dismissed the plaintiff's claim on the grounds that the plaintiff was not in the class of people entitled to sue under the FHA. ${ }^{148}$ The Ninth Circuit Court of Appeals affirmed. ${ }^{149}$ A unanimous Supreme Court reversed. ${ }^{150}$ It observed that "[t]he language of the Act is broad and inclusive," that the Act carries out a "policy that Congress considered to be of the highest priority," and that vitality can be given to this policy "only by a generous construction of the statute." 151

Thus, even though Congress likely was not thinking of plaintiffs or injuries of this type when it passed the FHA, the letter and the spirit of the statute still reached this claim. This is precisely the same reasoning the Bostock court relied on in interpreting Title VII.

In addition, it might be more important for sexual orientation to be considered a sex-based protected characteristic under the FHA. The housing context makes it more likely that a prospective landlord will be aware of a tenant's sexual orientation than would be the case for an employee in the workplace. This is because residential leases require the names of every person who will reside in a unit, and many require a statement of their relationship. Thus, a landlord will know if two people of the same sex are living together. If they are sharing a one-bedroom apartment, or have the same last name-or are married-they are effectively "outed." This is true regardless of whether they display other gender nonconforming behavior (thus making a bootstrapped Price Waterhouse theory of discrimination unavailable). Moreover, housing discrimination against couples based on their relationship to one another harms both of them, as well as everyone else in their household. Indeed, the FHA has long been used to address discrimination against people based on their romantic associations with one other. This has been most notably the case with interracial couples. Courts have frequently used the Loving theory of association (cited in Hively) to hold that housing discrimination against interracial couples constitutes discrimination based on race. ${ }^{152}$

\footnotetext{
147. Id. at 208.

148. Id.

149. Id.

150. Id.

151. Id. at 209-12 (internal citations omitted). The Supreme Court again referred to "the broad remedial intent of Congress embodied in the [Fair Housing] Act" in another unanimous Fair Housing Act opinion. See Havens Realty Corp. v. Coleman, 455 U.S. 363, 380 (1982). See also City of Edmonds v. Oxford House, Inc., 514 U.S. 725, 731 (1995) (reaffirming Trafficante's recognition of the Fair Housing Act's "broad and inclusive compass" and therefore its entitlement to a "generous construction").

152. Meyer v. Holley, 537 U.S. 280, 288 (2003); United States v. Big D Enters., 184 F.3d 924, 928 (8th Cir. 1999); United States v. Hylton, 944 F. Supp. 2d 176, 187-88 (D. Conn. 2013); Oliver v. Shelly, 538 F. Supp. 600, 601-02 (S.D. Tex. 1982).
} 


\section{MiXed MotiVE ANALYSIS}

There is, however, one issue that might complicate the analysis and, as in the cases described in the previous Section, give housing courts pause before they adopt Bostock's reasoning. The identical "because of . . sex" language in both Title VII and the FHA operates as a causation requirement. ${ }^{153}$ Courts struggle with the contours of this requirement, recognizing that both statutes are intended to eradicate discrimination based on protected characteristics, while also preserving a landlord or employer's ability to take legitimate factors into consideration. This leads to the so-called "mixed motives" problem: what happens when there is evidence that a defendant was motivated by both permissible and impermissible factors when it took action against a plaintiff? At what point can the court determine that discrimination constitutes discrimination "because of" a protected characteristic, even when there are other possible causes? The two statutes differ in their treatment of this issue. This Section discusses these differences, and whether they impede applying Bostock's analysis to the FHA.

\section{A. Mixed Motives Analysis Under Title VII and the FHA}

Courts have struggled with the mixed motives issue in the Title VII context. The legislative history of Title VII indicates that Congress did not mean to require proof that impermissible discrimination was the defendant's sole motivation. ${ }^{154}$ Nor, however, did Congress originally mean to create liability when discriminatory intent played a negligible role in a defendant's decision making. ${ }^{155}$ Thus, something other than traditional "but-for" liability was warranted, but the courts were left without guidance on what the standard of causation should be.

In Price Waterhouse the Court heard evidence that the defendant was motivated by a combination of permissible reasons and impermissible gender stereotyping when it failed to promote Ann Hopkins to partner. ${ }^{156}$ The Court failed to reach a majority opinion about the causation issue. Justice Brennan, writing for the plurality, held that once an employee establishes by a preponderance of the evidence that sex motivated an

\footnotetext{
153. Compare 42 U.S.C. $§ 2000 \mathrm{e}-2$, with 42 U.S.C. $\$ 3604$.

154. An amendment which would have added the word "solely" to the bill, modifying "sex," was defeated on the floor in the House of Representatives. See Bonnie H. Schwartz, Price Waterhouse v. Hopkins, 57 U.S.L.W. 4469 (U.S. May 1, 1989) (No. 87-1167): Causation and Burdens of Proof in Title VII Mixed Motive Cases, 21 ARIZ. ST. L.J. 501, 511 n.67 (1990) (citing 110 CONG. REC. 13,83738 (daily ed. June 1964) (statement of Sen. McClellan)).

155. Id. at 511-13.

156. Price Waterhouse v. Hopkins, 490 U.S. 228, 233-35 (1989) (plurality opinion).
} 
employment decision in any way, the burden then shifts to the employer. ${ }^{157}$ The employer may avoid a finding of liability only if it proves by a preponderance of the evidence that it would have made the same decision absent its unlawful consideration of sex. ${ }^{158}$ Justice O'Connor wrote separately to argue that the plaintiff must prove that unlawful discrimination was a "substantial factor" in the defendant's decision making, a conclusion that Justice White agreed with. ${ }^{159}$ Justice Kennedy, dissenting, pointed out that even though the plurality repudiated a construction of the "words 'because of' as colloquial shorthand for 'butfor causation,"" 160 its approach essentially created just that, only with burden-shifting at the back end. ${ }^{161}$

In 1991 Congress codified this standard when it amended Title VII. The Civil Rights Amendments Act established that "an unlawful employment practice is established when the complaining party demonstrates that race, color, religion, sex, or national origin was a motivating factor for any employment practice, even though other factors also motivated the practice." 162 The statute also included the "samedecision" defense, but made it only a partial defense. ${ }^{163}$ Thus, a defendant who successfully argues this defense can escape liability for compensatory and punitive damages, but can still be liable for injunctive relief and attorney's fees. ${ }^{164}$

The Fair Housing Act has not been amended in this way. Prior to the 1991 Act, courts hearing fair housing cases relied on Price Waterhouse. Courts continued to do so after the 1991 Act, arguing that the Court's

157. Id. at 250 ("In saying that gender played a motivating part in an employment decision, we mean that, if we asked the employer at the moment of the decision what its reasons were and if we received a truthful response, one of those reasons would be that the applicant or employee was a woman.").

158. Id. at 252 .

159. Id. at 262-69 (O'Connor, J. concurring). The various factions of the court also disagreed with how the plaintiff makes this showing (e.g., whether direct or circumstantial evidence would suffice) and the standard of proof each side must bear (preponderance of the evidence or clear and convincing evidence). Id. at 249-55 (Brennan, J., plurality opinion); Id. at 259 (White, J., concurring); Id. at 266 (O’Connor, J., concurring); Id. at 287-88 (Kennedy, J., dissenting).

160. Id. at 240 (Brennan, J., plurality opinion).

161. Id. at 283 (Kennedy, J., dissenting) ("One of the principal reasons the plurality decision may sow confusion is that it claims Title VII liability is unrelated to but-for causation, yet it adopts a butfor standard once it has placed the burden of proof as to causation upon the employer. This approach conflates the question whether causation must be shown with the question of how it is to be shown.").

162. 42 U.S.C. $\S 2000 \mathrm{e}-2(\mathrm{~m})$. Thus, the history of the mixed motive issue is similar to that of disparate impact theory, discussed in the previous Section. Both concepts were originally introduced to Title VII jurisprudence by the Supreme Court, and both were later incorporated into the statute by congressional amendment. See supra notes 119-24 and accompanying text. The Fair Housing Act has not been amended to include these theories.

163. 42 U.S.C. $\$ 2000 \mathrm{e}-5(\mathrm{~g})(2)(\mathrm{B})$.

164. Id. 
original interpretation of the "because of" language was still sound. ${ }^{165}$ Given the identical statutory language and long history of FHA cases relying on Title VII precedent, most advocates assume this is the proper approach, though the Supreme Court has never ruled on the issue. ${ }^{166}$

Another case dealing with a different employment discrimination statute casts doubt on whether the Price Waterhouse mixed motive standard should govern housing discrimination cases. In 2009 the Court decided Gross v. FBL Financial Services, Inc. ${ }^{167}$ which dealt with mixed motive cases under the 1967 Age Discrimination in Employment Act (ADEA). Like the FHA, the ADEA has identical "because of" language and has not been amended to include a mixed motives theory. ${ }^{168}$ In Gross, the Court determined that the Price Waterhouse standard did not apply in ADEA mixed motive cases because Congress did not amend the ADEA when it amended Title VII, even though it contemporaneously amended the ADEA in several other ways. ${ }^{169}$ Free to examine the issue as one of first impression, a bare majority of the Court refused to endorse the mixed motive theory, arguing that Price Waterhouse was difficult to apply and created confusion for lower courts. ${ }^{170}$ The 5-4 decision held that the proper standard should be "but-for" causation and that the plaintiff should retain the burden of persuasion throughout such a case "to establish that age was the 'but-for' cause of the employer's adverse action." 171

Thus, if Price Waterhouse does apply to housing cases with mixed motives, the plaintiff need only show that impermissible discrimination played some role in the challenged housing decision. The burden then shifts to the defendant, who will be liable unless it can prove by a

165. E.g., United States v. Big D Enters., 184 F.3d 924, 931-32 (8th Cir. 1999); Cato v. Jilek, 779 F. Supp. 937, $943-44$ (N.D. Ill. 1991).

166. Robert G. Schwemm, Housing Discrimination: Law and Litigation, § 10:3 (1990).

167. 557 U.S. 167, 169-70 (2009).

168. 29 U.S.C. $\S 623$ (a).

169. The Court noted that "[w]hen Congress amends one statutory provision but not another, it is presumed to have acted intentionally, and "negative implications raised by disparate provisions are strongest" where the provisions were "considered simultaneously when the language raising the implication was inserted." Gross, 557 U.S. at 174-75 (quoting EEOC v. Arabian Am. Oil Co., 499 U.S. 244, 256 (1991)). In contrast, Congress did not simultaneously amend the FHA when it amended Title VII, so this argument should carry little weight in a fair housing case.

170. Id. at 179 .

171. Id. at 175-78. Another case from the October 2020 term, Comcast Corp. v. Nat'l Ass'n of Afr. Am.-Owned Media, 140 S. Ct. 1009 (2020), provides another example of the current Court's reluctance to deviate from the but-for causation standard. In this case, the Court was asked whether a plaintiff bringing a case under 42 U.S.C. $§ 1981$ was required to plead (and prove) that racial animus was the "but-for" cause of the defendant's actions, or whether a more lenient pleading standard might apply. Comcast Corp., 140 S. Ct. at 1013-14. The Court held there was no reason to deviate from the "but-for" causation standard. Id. at 1019. This has little bearing on the present matter, however, because the Court grounded its analysis in the text, structure, and history of $\S 1981$, which differs in significant and material ways from both Title VII and the FHA. 
preponderance of the evidence that it would have taken the same action in the absence of the illegal consideration. If the defendant satisfies this burden, it will not be liable under the FHA. If Price Waterhouse does not apply to housing cases with mixed motives, the plaintiff will not succeed unless she can demonstrate that impermissible discrimination was a "butfor" cause of the negative action.

\section{B. Bostock, Mixed Motives, and the FHA}

The question, then, is what do these different approaches to mixed motive theory mean for housing cases after Bostock? The Bostock majority opinion spends a significant amount of time dissecting what the phrase "because of... sex" means from the standpoint of causation. Indeed, the "tried and true" comparative method articulated in Hively and adopted in Bostock is essentially a causation test. It requires holding all factors constant except for the tested variable (in this case, the sex of the plaintiff), in order to determine the causative effect of the variable. As Justice Gorsuch explained:

An employer violates Title VII when it intentionally fires an individual employee based in part on sex. It doesn't matter if other factors besides the plaintiff's sex contributed to the decision.... If the employer intentionally relies in part on an individual employee's sex when deciding to discharge the employee - put differently, if changing the employee's sex would have yielded a different choice by the employera statutory violation has occurred. ${ }^{172}$

The Court started from the premise that "homosexuality and transgender status are distinct concepts from sex," ${ }^{173}$ and attempted to tease out the role that "sex" plays in sexual orientation and gender identity discrimination:

Often, events have multiple but-for causes. So, for example, if a car accident occurred both because the defendant ran a red light and because the plaintiff failed to signal his turn at the intersection, we might call each a but-for cause of the collision. When it comes to Title VII, the adoption of the traditional but-for causation standard means a defendant cannot avoid liability just by citing some other factor that contributed to its challenged employment decision. So long as the plaintiff's sex was one but-for cause of that decision, that is enough to trigger the law. ${ }^{174}$

Passages like this appear to invoke the mixed motives theory, which

172. Bostock v. Clayton Cnty., 140 S. Ct. 1731, 1741 (2020).

173. Id. at $1746-47$.

174. Id. at 1739 (internal citations omitted). 
involves judicial interpretation (and later statutory clarification) of the "because of sex" language. Put another way, at first blush it appears the Court is examining two factors - one arguably permissible (discrimination based on sexual orientation/gender identity) and one prohibited (discrimination based on sex) - and trying to figure out the causative role that each plays in a decision. If this is the case, then applying the Court's analysis to the FHA might be difficult, as the particular type of mixed motives analysis differs from the Title VII context. Recall that under Title VII, a defendant is liable when impermissible discrimination plays any role in its decision. The defendant carries the burden of proving a samedecision defense, but even if successful this will only be a partial defense - a shield for damages. Under the FHA (at least to the extent that it follows Price Waterhouse), a mixed motives theory is also available, but the same-decision defense will serve as a complete defense to liability. If Price Waterhouse does not apply, then a plaintiff must demonstrate that impermissible discrimination was the "but-for" cause of the negative action.

Does this mean that a sexual orientation/gender identity claim is harder for a FHA plaintiff than a Title VII plaintiff? Will it be possible for an FHA defendant to argue that it would have made the same decision to discriminate based on the "permissible" factors of sexual orientation/gender identity regardless of the fact that an impermissible factor (sex) played a role? Would an FHA plaintiff have to demonstrate that discrimination based on the protected characteristic was the primary or motivating factor? Do these differences in interpreting "because of sex" with respect to mixed motive cases mean that Bostock's "because of sex" analysis should not even apply to FHA cases?

The simple answer is no. While it might have superficially seemed like Bostock was engaged in mixed motives analysis when it used the comparative method, in fact, it was not. There were not two possible motives at play, one permissible and one prohibited. Instead, the Court recognized that, while the characteristic of sex is not the same as sexual orientation and gender identity, it cannot be disaggregated from them either. ${ }^{175}$ Sex is inextricably bound up in both of these concepts. As the Bostock Court acknowledged, "discrimination based on homosexuality or transgender status necessarily entails discrimination based on sex; the first cannot happen without the second." 176 The Court went on to clarify:

$[\mathrm{H}]$ omosexuality and transgender status are inextricably bound up with

175. Id. at $1741-47$.

176. Id. at 1747 . 
sex. Not because homosexuality or transgender status are related to sex in some vague sense or because discrimination on these bases has some disparate impact on one sex or another, but because to discriminate on these grounds requires an employer to intentionally treat individual employees differently because of their sex. ${ }^{177}$

If, as the Court concluded, "it is impossible to discriminate against a person for being homosexual or transgender without discriminating against that individual based on sex," then there are no mixed motives here-if anything, the motives are interlocking. ${ }^{178}$ Thus, there should be no problem with applying Bostock's analysis that the term "because of sex" in Title VII includes sexual orientation and gender identity to the FHA because the FHA contains identical language. The two statutes may differ when it comes to mixed motives analysis, but this issue does not actually implicate mixed motives.

\section{CONCLUSION}

There should be little doubt that the Court's reasoning in Bostockthat the prohibition on discrimination "because of sex" in Title VII encompasses discrimination based on sexual orientation and gender identity - should apply with equal force to identical language in the Fair Housing Act. The two statutes have a similar language, structure, and purpose. As a result, courts have long used Title VII analysis to guide their interpretation of the FHA. There are no relevant differences between the housing and employment contexts when it comes to this issue that might give courts pause. The slight differences between the two statutes with respect to the mixed motives theory should not create an impediment, because the issue of sexual orientation and gender identity discrimination does not, in fact, implicate mixed motives at all.

On January 20, 2021, President Biden issued an executive order addressing Bostock and directing federal agencies to enforce the law in a manner consistent with that opinion. ${ }^{179}$ As this Article was being prepared for publication, HUD became the first agency to do so. HUD's Office of Fair Housing and Equal Opportunity (FHEO) issued a memorandum stating that, in light of the Executive Order and Bostock, it would begin enforcing the FHA to combat discrimination on the basis of sexual

177. Id. at 1742 .

178. Id. at 1741. To put the final point on this, the Court emphasized that "nothing in our analysis depends on the motivating factor [but-for cause] test." Id. at 1740.

179. Exec. Order No. 13988, 86 Fed. Reg. 7023 (Jan. 20, 2021). 
orientation and gender identity. ${ }^{180}$ The memo states:

Effective immediately, FHEO shall accept for filing and investigate all complaints of sex discrimination, including discrimination because of gender identity or sexual orientation, that meet other jurisdictional requirements..... Similarly, FHEO shall conduct all other activities involving the application, interpretation, and enforcement of the Fair Housing Act's prohibition on sex discrimination to include discrimination because of sexual orientation and gender identity. ${ }^{181}$

While this memo only applies to HUD, and does not technically bind courts in private lawsuits, it is still significant for a number of reasons. First, HUD's FHEO itself processes a significant minority of administrative housing discrimination complaints. Second, as an agency charged with enforcement of the FHA, HUD's interpretation of the statute is entitled to some deference by courts. Finally, the memo affects state and local agencies that enter into agreements with HUD under its Fair Housing Assistance Program (FHAP). Such agencies process the majority (approximately 80\%) of administrative housing discrimination complaints filed in the U.S. They can receive funding and technical support for processing state housing discrimination claims, so long as the law of their state is certified as "substantially equivalent" to the federal FHA. As the memo makes clear:

In order for FHAP agencies' laws to remain substantially equivalent, they must be administered consistent with Bostock. To be consistent with Bostock, the state or local law either must explicitly prohibit discrimination because of gender identity and sexual orientation or must include prohibitions on sex discrimination that are interpreted and applied to include discrimination because of gender identity and sexual orientation. ${ }^{182}$

Agencies in thirty-seven states currently participate in the FHAP

180. Memorandum from the U.S. Dep't of Hous. \& Urb. Dev. on Implementation of Executive Order 13988 on the Enforcement of the Fair Housing Act (Feb. 11, 2021), https://www.hud.gov/sites/dfiles/PA/documents/HUD_Memo_EO13988.pdf [https://perma.cc/PP $5 \mathrm{~N}-3 \mathrm{~S} 3 \mathrm{~A}]$.

181. Id. at 2 .

182. Id. 
program, ${ }^{183}$ receiving a total of roughly twenty-four million dollars. ${ }^{184}$ Currently, eleven of these states neither explicitly prohibit discrimination based on sexual orientation and gender identity, nor interpret their existing prohibitions to cover these characteristics. ${ }^{185}$ Thus, these states risk losing significant federal assistance in enforcing their fair housing laws. The risk of losing these funds might provide an incentive for these states to amend their laws to reflect President Biden's Executive Order.

Bostock was a significant win for the LGBTQ community, and it will undoubtedly have ramifications for other remedial civil rights laws. In the absence of Congressional action to protect LGBTQ individuals from discrimination, the Supreme Court has stepped in to read these protections back into the law. While some may question the propriety of this practice from a separation of powers perspective, the Court has clearly staked out a position on this issue. In the coming litigation that will inevitably ensue under other statutes, there is no reason to think that the Court's reasoning should be limited to the employment context. This is especially true for fair housing cases and should result in much-needed legal protections for LGBTQ individuals.

183. Fair Housing Assistance Program (FHAP) Agencies, HUD, https://www.hud.gov/ program_offices/fair_housing_equal_opp/partners/FHAP/agencies [https://perma.cc/4GE7-CN5A] (last visited Feb. 18, 2021).

184. FAIR HOUS. \& EQUAL OPPORTUNITY FAIR HOUS. Programs, 2019 SUMMARY STATEMENT AND INITIATIVES 2 (2020), https://www.hud.gov/sites/dfiles/CFO/documents $134 \% 20-\% 20 \mathrm{FY} 19 \mathrm{CJ} \% 20-\% 20 \mathrm{FHEO} \% 20-\% 20 \mathrm{Fair} \% 20$ Housing\%20Programs.pdf [https://perma. cc/9WFZ-TR4B].

185. Nondiscrimination Laws, supra note 27. The states are: Arizona, Arkansas, Florida, Georgia, Kentucky, Louisiana, North Carolina, South Carolina, Tennessee, Texas, and West Virginia. 